\title{
The Role of Information in the U.K. Passenger Rail Industry
}

\author{
Glenn Lyons and Graeme McLay \\ University of Southampton, United Kingdom
}

\begin{abstract}
In 1993, the U.K. passenger rail industry was privatized with expectations of greater investment, increased efficiency, and improved network performance. To date, progress has been mixed and the industry has been subject to a critical national press and passenger complaints that have reached record levels. The industry is continuing to develop a service that can do justice to its privatization. Passenger information is an important aspect of these improvements and national rail journey planning services are now heavily used. However, relatively little consideration has been given to understanding the role that information might play in assisting passengers who have already planned their journey but who encounter problems when they travel by train.

Failure to execute a journey as planned can be severely disruptive to rail passengers in terms of lost time, expense, anxiety, and frustration. This article charts the development of the privatized rail industry and defines a set of journey breakdown situations that can be encountered by passengers. Insights are gained from passenger complaint letters. Such letters typically provide detailed accounts of journey breakdowns, attempts to recover the situations, and the use made of available information. Inaccurate or misunderstood pretrip information is found to be a factor in many journey breakdowns. Accessible, timely, and appropriate provision of en-route information can improve passengers'satisfaction by enabling completion of their immediate journey and might also be decisive in ensuring they have the confidence to use the rail network again in the future.
\end{abstract}




\section{Introduction}

During the 1990s, the United Kingdom transitioned its passenger rail from a nationalized system to a privatized industry. Table 1 summarizes the history of the industry and highlights the key organizations that comprise today's provision of passenger rail in the United Kingdom. For further details concerning the privatization process, including economic impacts and a view on the restructured railway, see White (1998), Organization for Economic Cooperation and Development (1998), and Welsby and Nichols (1999).

Despite the technological advances made between Stephenson's rocket (1829) and the modern interurban trains operating in the United Kingdom, such advances are not reflected in current journey times and punctuality. For example, the current Great Britain Passenger Railway Timetable allows 44 minutes for the Portsmouth to Southampton train that, in 1898, took just 35 minutes (Leake and Macaskill 1998). This is not merely because there are now more stations, although it may be due to higher numbers of trains on the network.

A lack of investment in rail infrastructure has led to increased delays and unreliability (Department of the Environment, Transport [DETR] and the Regions 1998). According to the Shadow Strategic Rail Authority (SSRA 1999), only 8 out of 25 Train Operating Companies (TOCs) are achieving both 90 percent or higher punctuality and 99 percent or higher reliability. ("Punctual" is defined by the SSRA as being within 10 minutes of the stated arrival time for interurban routes, 5 minutes for local routes, and 30 minutes for sleeper trains. "Reliable" is defined as a train completing at least $50 \%$ of its scheduled route mileage.) From April 1, 1998, through March 31, 1999, the TOCs registered over 1 million complaints from passengers (737,331 written), an increase of 12 percent from the previous year. This represents 122 complaints per 100,000 journeys (Office of the Rail Regulator [ORR] 1999). Of these complaints, 55 percent concerned train service performance (Figure 1). The Rail Regulator considered that these figures did not fully reflect passenger dissatisfaction, but that they did depict a rail industry that was increasingly failing the customer. Yet there may be other reasons why 


\section{Table 1}

\section{Chronological Overview of the U.K. Passenger Rail Industry}

Pre-1921 A railway system in the United Kingdom evolved. It was comprised of a plethora of independent railway companies with their own lines and procedures.

1921 By this date, amalgamation with a need to improve commercial viability led to a railway system comprised of four companies.

1948 Companies were nationalized and became the Railway Executive.

1962 The Railway Executive was replaced by the British Railways Board (BRB) with the railway component of the enterprise known as British Rail (BR). Central government grants provided for loss-making routes.

1963 The Beeching Report (BRB 1963) signaled closure of lightly used parts of the rail network.

1983 The Serpell Inquiry (Her Majesty's Stationery Office 1983) brought forth public outcry to prevent more line closures.

1988/89 Government grants total $1700 \mathrm{M}$ with no sign of reduction in this level of subsidy.

1993 The Railways Act was passed bringing about privatization of the passenger rail industry with hopes of greater efficiency. BR was divided into its component parts: Railtrack (infrastructure), TOCs (passenger services), and Rolling Stock Companies (ROSCOs) providing/leasing passenger rolling stock to the TOCs. The ORR was created to oversee operation of the privatized industry.

1994 The Association of Train Operating Companies (ATOC) was formed to act as a trade organization for the 25 TOCs.

1997 ATOC began operation of a National Rail Enquiry Service (NRES) with telephone call centers providing timetable and fare information.

1998 A U.K. Transport White Paper was published with a policy emphasis on integrated transport. Establishment of a Strategic Rail Authority (SRA) was proposed to provide a focus for strategic planning with powers to influence the behavior of key industry players DETR (1998). This was established in shadow form prior to the necessary legislation being passed.

Post-2000 A transport bill is currently passing through Parliament with the necessary legislation for establishment of the SRA. 


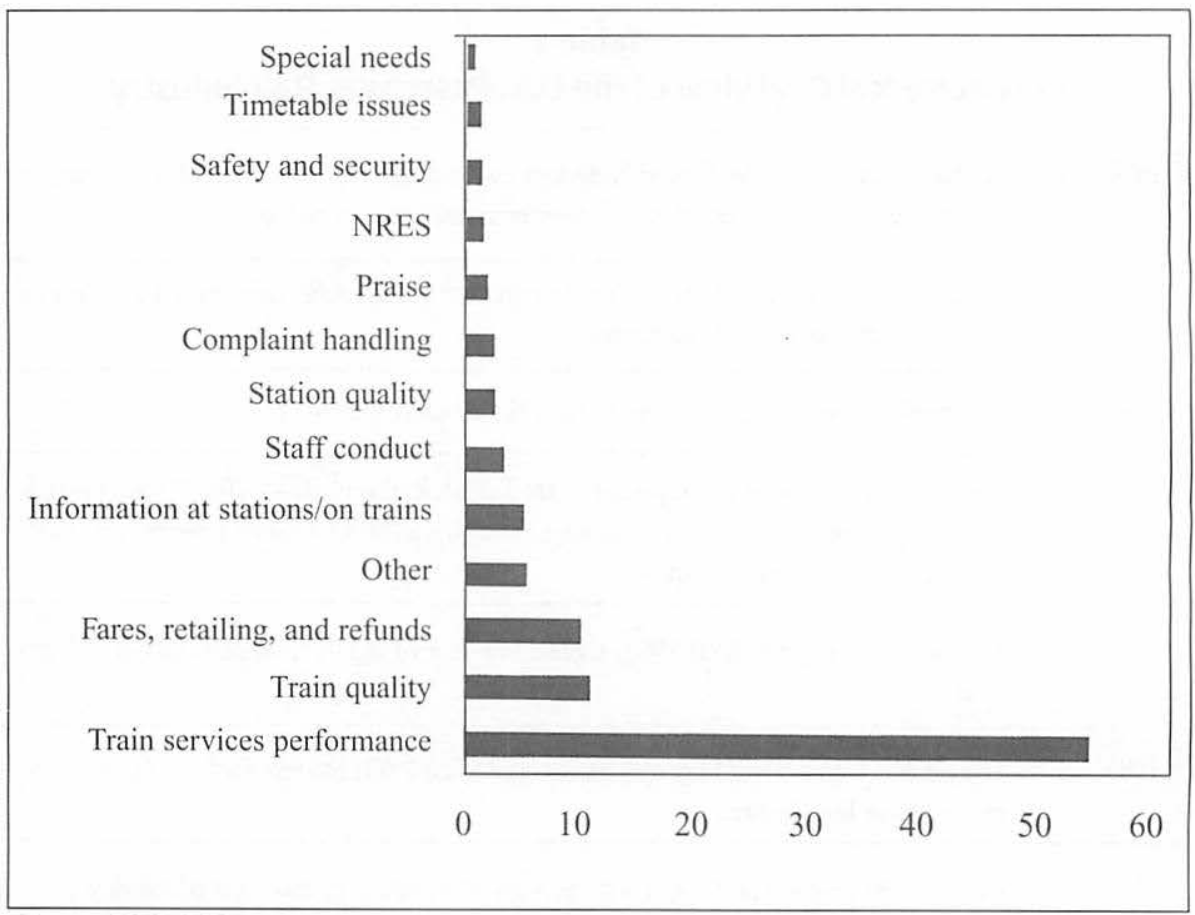

Source: ORR 1999.

\section{Figure 1. Distributions of passenger complaints made to the TOCs by complaint category}

complaints are rising. Individual train operators and government bodies have introduced complaint procedures. The Rail Regulator has encouraged complaint collection. Press coverage of complaints has brought complaining to peoples' attention, as has the prospect of compensatory payments to complainants. To encourage more people to use the rail network, rail companies will need to overcome the perception that rail travel is something about which to complain.

Passenger information represents a key means by which the extent of adverse reaction to rail travel might be redressed. The nature of public transport information and the role it can perform is summarized by Le Squeren (1991) as shown in Table 2.

Complementary to Table 2, Anderson (1993) identified six objectives for a passenger rail information system (stemming from similar objectives relating to the London Underground): 
1. assist passengers in planning and during their journeys;

2. improve passengers' efficiency of movement through the system (leading to a reduction in travel time, or their perception of it);

3. provide reassurance and confidence to passengers (indicating that staff know what is happening and are in control);

4. advise passengers if changes in their route become necessary;

5. enhance the quality and range of services offered (with the aim of attracting more passengers); and

6. provide staff with a better picture of what is happening (to enable them to effectively respond to inquiries from passengers).

\begin{tabular}{|c|c|}
\hline \multicolumn{2}{|r|}{$\begin{array}{l}\text { Table } 2 \\
\text { Functions of Traveler Information }\end{array}$} \\
\hline \multicolumn{2}{|r|}{ Promotional Role } \\
\hline Mobility & Propose destinations and/or reasons for traveling \\
\hline Presence & $\begin{array}{l}\text { Tell people about public transport: include public transport in the range of options } \\
\text { open to people }\end{array}$ \\
\hline Image & Improve the image of public transport, highlight its advantages \\
\hline \multicolumn{2}{|r|}{ Teaching Role } \\
\hline Learning & Facilitate understanding of how to use public transport (tickets, fares, etc.) \\
\hline Conforming & Familiarize patrons with the rules of conduct for a collective system \\
\hline \multicolumn{2}{|r|}{ Operational Role } \\
\hline Trip planning & $\begin{array}{l}\text { Facilitate the preparation and planning of journeys on public transport (schedules, } \\
\text { etc.) }\end{array}$ \\
\hline Access & Facilitate access to the network (reductions) \\
\hline Travel & Facilitate the journey itself (indications, identification, guidance) \\
\hline Arrival & Facilitate the onward journey after arrival \\
\hline Modification & $\begin{array}{l}\text { Inform users of and explain reasons for modifications with respect to scheduled } \\
\text { service }\end{array}$ \\
\hline \multicolumn{2}{|r|}{ Appropriation Role } \\
\hline Atmosphere & Participate in creating the physical and psychological atmosphere of the journey \\
\hline Control & Give patrons more control over their journey and the various options available to them \\
\hline
\end{tabular}

Source: Le Squeren (1991). 
Passenger information can improve understanding of what the passenger rail industry has to offer, enable journey planning, and provide travel itineraries that assist journey execution. It does not materially improve rail services, increase punctuality or frequency, or reduce service journey times or costs. However, it can empower the passenger to make confident and effective use of what is available. Passengers value information.

Availability of information is increasing and, in turn, passenger propensity to seek information and their expectation to find it available are both also increasing. Access to telephone- and Internet-based information systems predominantly concerns pre-trip journey planning. Yet information has considerable potential to assist passengers during their journey. The complaints statistics given above suggest that at least 1 million rail passengers a year suffer some disruption to their journey. In some cases, existing provision of information may have served to alleviate frustrations and instruct passengers on any changes necessary to complete their journey. However, in many cases, passengers will have suffered unnecessary delay, inconvenience, irritation, and possible expense because of an absence of information to enable them to address the disruptions to their journey.

This article offers an initial consideration of the opportunities for information provision in situations where a passenger's journey has "broken down" and where access to suitable information could assist in "recovery" of the journey. Complaint letters provide a useful insight into journey breakdowns encountered by passengers and typically include a detailed account of a passenger's experience and attempts to recover the journey including the use of information. Complaint letters received by the ATOC are examined and a classification of journey breakdown situations is developed.

\section{U.K. Passenger Rail Information Systems}

Under BR, local stations responded to local train inquiries; under postprivatization, stations do not pass on journey information by telephone. The NRES is provided on behalf of the TOCs by ATOC and is accessible from a single national telephone number, 24 hours a day, 7 days a week (ATOC 2000). The 
NRES handled approximately 60 million calls in 1999, compared to 52 million in 1998 and 37 million in 1997. Recent (unpublished) research undertaken by ATOC demonstrated that the NRES is revenue generative and makes a valuable contribution to passenger services' finances.

This service uses the Great Britain Passenger Railway Timetable as its basis for timetable information, stored in electronic form in such a way that schedule information can be provided in response to inquiries. In the event that changes to the timetable occur, and with at least 36 hours' notice, these can be sent to the NRES and the timetable can be amended. In the event of an emergency or serious incident, each of the six call centers that operate the NRES are contacted. Call center operators are then expected to take account of this information where it affects routes relating to passenger inquiries. The NRES uses separate systems for fares and timetables. A new Rail Journey Information Service (RJIS) that combines information on fares, timetables, and reservations is currently working in preproduction mode. Real-time train running information will be an additional facility introduced in late 2000. It is expected to be able to handle 5 million queries a month-at least 70 queries a minute (Computing 1998). This system will be able to identify when a train has been delayed, and could then pass this information on to passengers, along with advice about alternative routes.

More than 94 percent of homes in the United Kingdom have a telephone (Office for National Statistics 2000) and hence have access to the NRES for pretrip information. The 1999 Which? Annual Internet Survey (see $\mathrm{http}: / / \mathrm{www} . w h i c h . n e t)$ estimated that approximately 14 percent of Britons were using the Internet. More recent survey results suggest that at the end of 1999 this figure was closer to 20 percent (Internet Magazine 1999). Access is set to increase dramatically in the home and workplace and via mobile communications. The rail industry is responding to this trend with websites that offer information comparable to that from the NRES (Lyons 1999). Railtrack's website (http://www.railtrack.co.uk) provides a journey planner for national rail inquiries. (Railtrack has an obligation to make the Great Britain Passenger Railway Timetable available to 
the public.) In 1999, the site processed a similar number of journey planning inquiries to the number of calls handled by the NRES (Railtrack 2000). The TrainLine (http://www.thetrainline.com) is a commercial on-line service that is now being promoted by a strong marketing campaign. It provides both journey planning and fare information with the option of on-line booking and payment.

Access via telephone or Internet to information for pre-trip journey planning is generally very good. From the 60 million calls made to the NRES in 1999, the level of NRES-related complaints is 0.03 percent. Information is also available at stations via station staff, timetable boards and terminals, kiosks, and Help Points (providing intercom access on platforms to rail staff). Much of this information is historical rather than contemporary or predictive. Some kiosks have modem links, but others require manual updates.

Until all trains run precisely to schedule, there will be a need for collection and dissemination of real-time information. The U.K. rail industry is investigating ways to exploit information and communications technology to gather and distribute such information. For example, ScotRail has tested a Global Positioning System (GPS) to try to pinpoint trains and provide customers with more accurate information (Campbell 1998). This has led to a countdown and map display to provide passengers with arrival times within 25 seconds of accuracy.

There is a need to understand how rail information systems might be further developed and used in supporting passengers en route whose journeys have suffered a setback and who must replan the remainder of their journey. This may call for a more passenger-oriented rather than a systems approach to journey recovery as replanning may include the (partial) use of another (public transport) mode. Cooperation and partnership across the public transport industry is enabling the current development of a National Public Transport Information System that will be available via a single telephone number as with the NRES. The system is a goal set out in the government's Transport White Paper (DETR 1998). It will aim initially to provide a timetable-based journey inquiry service 
across public transport modes down to a bus-stop/street level of detail. The system is unlikely to offer relevant and sufficient information appropriate for unscheduled rail journey recovery situations, at least in the short term.

To explore the potential information needs for journey recovery, it is necessary to identify the types of journey breakdowns that can occur.

\section{Journey Breakdowns}

A journey breakdown can be defined as a failure to execute a journey as planned. In some cases, a breakdown will be the fault of the traveler either directly, or indirectly as a consequence of problems associated with the means of transport used to reach the station. In other cases, it will be the actual or perceived fault of the rail industry in terms of information provided or its interpretations, or through a lack of information to enable the traveler to complete the journey as planned. In further situations, a journey breakdown will be a direct result of a failing of the train service in terms of not operating according to the timetable. Consideration was given to the ways in which a journey might suffer a setback. This resulted in a set of journey breakdown scenarios as shown in Table 3 (see Adenso-Diaz et al. 1999 for another list of possible incidents leading to rescheduling, or Higgins and Kozan 1998 for different delay types). An interpretation of the likely consequences, recovery options, and information needs for each scenario is also given in Table 3.

The passenger rail industry is aware of the importance of information. However, it will need to be convinced of the merits of further investment in its information provision to specifically support passengers needing to establish recovery options following a journey breakdown. To accomplish this, the following steps are suggested:

1. Determine the frequency of occurrence nationally of each breakdown scenario over a given time period.

2. For each scenario, establish an estimate of the average "level" of recovery that is possible, given perfect information, in terms of delay saving and monetary cost. Other measures constituting generalized travel cost 


\begin{tabular}{|c|c|c|c|}
\hline \multicolumn{4}{|c|}{$\begin{array}{c}\text { Table } 3 \\
\text { Rail Journey Breakdown Scenarios }\end{array}$} \\
\hline No. & Scenario & Consequences & $\begin{array}{l}\text { Recovery Options/ } \\
\text { Information Needs }\end{array}$ \\
\hline 1 & No problem & $\begin{array}{l}\text { Journey completed as } \\
\text { planned. }\end{array}$ & No recovery necessary. \\
\hline 2 & $\begin{array}{l}\text { Get to station, can't } \\
\text { locate train }\end{array}$ & $\begin{array}{l}\text { Will miss the train unless it } \\
\text { can be located. }\end{array}$ & $\begin{array}{l}\text { Signs, staff, and other passengers } \\
\text { can give directions. }\end{array}$ \\
\hline 3 & $\begin{array}{l}\text { At station, train is differ- } \\
\text { ent from that expected }\end{array}$ & $\begin{array}{l}\text { Time cost if passenger must } \\
\text { wait for another train. }\end{array}$ & $\begin{array}{l}\text { Need to find if train is suitable, or } \\
\text { change mode. }\end{array}$ \\
\hline 4 & $\begin{array}{l}\text { At station, find price is } \\
\text { different from (recollect- } \\
\text { ed) quote }\end{array}$ & $\begin{array}{l}\text { May miss train if not able or } \\
\text { willing to pay. Possible } \\
\text { anger and mistrust. }\end{array}$ & $\begin{array}{l}\text { Can still use train, if able/prepared } \\
\text { to pay new price, or could consider } \\
\text { alternative travel options. }\end{array}$ \\
\hline 5 & $\begin{array}{l}\text { Get to station, imminent } \\
\text { departure }\end{array}$ & $\begin{array}{l}\text { Miss train or try to pay on } \\
\text { board. Possible penalty. }\end{array}$ & $\begin{array}{l}\text { If train caught, then no problem. If } \\
\text { not, need information to proceed. }\end{array}$ \\
\hline 6 & $\begin{array}{l}\text { Get to station late, train } \\
\text { has gone }\end{array}$ & $\begin{array}{l}\text { Miss train, possibly cancel } \\
\text { trip. }\end{array}$ & $\begin{array}{l}\text { Catch up with the train, take a later } \\
\text { one, change mode, or cancel trip. }\end{array}$ \\
\hline 7 & Board wrong train & $\begin{array}{l}\text { Probable time cost and } \\
\text { potential additional mone- } \\
\text { tary cost. }\end{array}$ & $\begin{array}{l}\text { Return to origin, try to meet train, } \\
\text { take an alternative route, or take an } \\
\text { alternative mode. }\end{array}$ \\
\hline 8 & $\begin{array}{l}\text { Get to train, train } \\
\text { doesn't depart }\end{array}$ & Delay, possibly cancel trip. & $\begin{array}{l}\text { Find out what is happening, change } \\
\text { train, mode, or cancel trip. }\end{array}$ \\
\hline 9 & Train arrives late & Delay, possibly cancel trip. & $\begin{array}{l}\text { Find out if train will arrive, or } \\
\text { another option must be taken. }\end{array}$ \\
\hline 10 & Train cancelled & Delay, possibly cancel trip. & Find alternatives or cancel trip. \\
\hline 11 & Train departs late & $\begin{array}{l}\text { May miss connections. Lost } \\
\text { time may be recovered over } \\
\text { journey distance. }\end{array}$ & $\begin{array}{l}\text { Find out if the delay is sufficient to } \\
\text { warrant changing plans. }\end{array}$ \\
\hline 12 & $\begin{array}{l}\text { Train stops outside sta- } \\
\text { tion }\end{array}$ & Passengers must wait. & $\begin{array}{l}\text { Begin to plan for when the train } \\
\text { starts moving. }\end{array}$ \\
\hline 13 & $\begin{array}{l}\text { Train stops at intermedi- } \\
\text { ate station }\end{array}$ & $\begin{array}{l}\text { Delay while waiting for } \\
\text { action. }\end{array}$ & $\begin{array}{l}\text { Need information to decide whether } \\
\text { to stay with train, take alternatives, } \\
\text { or abandon trip and return to origin. }\end{array}$ \\
\hline 14 & $\begin{array}{l}\text { Train doesn't stop at } \\
\text { expected station }\end{array}$ & Delay, anxiety. & $\begin{array}{l}\text { Get off at next suitable stop for } \\
\text { return by appropriate mode. }\end{array}$ \\
\hline 15 & $\begin{array}{l}\text { Train runs behind } \\
\text { schedule }\end{array}$ & $\begin{array}{l}\text { Late to destination, may } \\
\text { miss connections. }\end{array}$ & $\begin{array}{l}\text { Remain with train or depart early to } \\
\text { try alternatives. }\end{array}$ \\
\hline 16 & $\begin{array}{l}\text { Train runs ahead of } \\
\text { schedule }\end{array}$ & $\begin{array}{l}\text { Arrive early. Possible wait } \\
\text { for collection or connection. }\end{array}$ & $\begin{array}{l}\text { Phone ahead to inform of early } \\
\text { arrival, catch other connections. }\end{array}$ \\
\hline 17 & $\begin{array}{l}\text { Passenger uses network } \\
\text { suboptimally }\end{array}$ & Time and/or financial costs. & $\begin{array}{l}\text { Use information to improve use of } \\
\text { network. }\end{array}$ \\
\hline
\end{tabular}


might also be considered.

3. Establish the propensity of passengers, given the availability of the necessary information, to pursue the recovery options identified.

4. Estimate the collective value to passengers, over the given time period, of providing information that enables journey recovery options to be determined.

5. Conduct a cost-benefit analysis of the provision of suitable tailored information.

Such an approach is difficult to pursue. Categorizing the complaints received annually by the industry according to the scenarios could enable step 1 to be completed. However, the industry does not currently record all complaints in a form to enable this to be done. Further, not all passengers who suffer a journey breakdown will register a complaint. Nevertheless, analysis of written complaints does provide a useful preamble to the five-step approach or similar in terms of acquiring a better understanding of the breakdown situations people face and the consequences that ensue.

\section{Analysis of Complaint Letters}

ATOC gave permission for its complaints files to be examined.

\section{Complaint Letters Held by ATOC}

The vast majority of written complaints about the rail service are sent directly to the individual TOCs concerned. A minority of written complaints about TOCs or the NRES are lodged with ATOC. These are filed for a minimum two-year period. By the middle of February 1999, ATOC had 105 letters of complaint on file (from the beginning of January 1998 to the end of January 1999); the TOCs received a million written and oral complaints in this time period (ORR 1999).

Complaint letters are inevitably not written to a common format with subsequent analysis in mind. However, there is a substantial degree of overlap in terms of the information they contain. The letters were treated retrospectively as a set of survey responses. A "data entry" schema was devised and used to elicit 
salient information from each of the 105 letters.

\section{Scenario Representation within Letters}

The complaint letters represent an extremely biased sample of journey breakdowns experienced. They address situations that are the fault of the rail service, not those that are the fault of the traveler, such as arriving late at the departure station and missing the train. They also represent journey breakdowns that were sufficiently disruptive to warrant a written complaint (or individuals with a higher propensity to lodge complaints).

Table 4 shows the representation of the 17 scenarios from Table 3 among the 105 complaints. (While it may seem peculiar for people with no problem to complain, some felt that information provision was inadequate despite not experiencing any difficulty.) Nearly all the scenarios were found within this relatively small sample of complaints.

It became apparent when reading the complaint letters that many of the sce-

\begin{tabular}{|c|c|c|c|}
\hline \multicolumn{4}{|c|}{$\begin{array}{c}\text { Table } 4 \\
\text { Scenario Occurrences in Assessment of Complaint Letters }\end{array}$} \\
\hline No./Scenario & $\begin{array}{c}\text { No. of } \\
\text { Complaints }\end{array}$ & Scenario & $\begin{array}{l}\text { No. of } \\
\text { Complaints }\end{array}$ \\
\hline 1. No problem & 3 & 10. Train cancelled & 22 \\
\hline 2. Get to station, can't locate train & 3 & 11. Train departs late & 5 \\
\hline $\begin{array}{l}\text { 3. At station, train is different from } \\
\text { that expected }\end{array}$ & 14 & 12. Train stops outside station & 1 \\
\hline $\begin{array}{l}\text { 4. At station, find price is different } \\
\text { from (recollected) quote }\end{array}$ & 22 & $\begin{array}{l}\text { 13. Train stops at intermediate } \\
\text { station }\end{array}$ & 9 \\
\hline $\begin{array}{l}\text { 5. Get to station, imminent } \\
\text { departure }\end{array}$ & 2 & $\begin{array}{l}\text { 14. Train doesn't stop at expected } \\
\text { station }\end{array}$ & 2 \\
\hline 6. Get to station late, train has gone & 2 & 15. Train runs behind schedule & 16 \\
\hline 7. Board wrong train & 1 & 16. Train runs ahead of schedule & 0 \\
\hline 8. Get to train, train doesn't depart & 0 & $\begin{array}{l}\text { 17. Passenger uses network } \\
\text { suboptimally }\end{array}$ & 1 \\
\hline 9. Train arrives late & 2 & & \\
\hline
\end{tabular}


narios identified were interrelated. A late-arriving train (9) probably also departs late (11). If passengers "give up" on this train, it becomes a train that does not depart (8). Trains with imminent departure (5), or where passengers cannot find the train (2), may become trains that have gone (6). Trains making unanticipated stops at stations (13) or on the line (12) will run behind schedule (15). Many passengers had to take a different train from that expected (3) because their train had been cancelled (10). Based on such considerations, the 17 scenarios can be translated into 5 journey breakdown bundles in terms of the recovery options that will need to be considered. These are summarized in Table 5 .

\section{Journey Breakdown Bundles}

There is a balanced distribution of complaints across bundles with the exception of the "no problem" bundle where, as expected, few complaints arise. Consideration of situations encountered within the complaint letters for each bundle provides some intriguing insights into the disruption suffered by rail passengers. It is only possible to provide a limited number of examples within this article.

No Train. The first bundle covers those cases where the passenger does not board the planned train at the origin. Pre-trip information, particularly station information, is available to these passengers. Several trips mentioned in the complaints to ATOC would have experienced no problem if the passenger had allowed more float time at the outset to catch an appropriate train. One passenger complained about missing the Barnham-Bognor train and being late for an interview. This train takes 6 minutes and runs every 10. In a further 14 cases, the journeys might not have needed to be recovered if people had been given the correct information to begin with: morning times were given instead of evening ones; summer schedules began, but passengers were not told about them. A passenger, who was advised by the NRES to take the 15:55 Banbury-London connecting with the Edinburgh train, noticed it was not on the departures board. Ticket staff then told him a special timetable was in operation during long-running engineering works. He was advised to take another train that only allowed 


\begin{tabular}{|c|c|c|c|}
\hline \multicolumn{4}{|c|}{$\begin{array}{c}\text { Table } 5 \\
\begin{array}{c}\text { Grouping of Journey Breakdown Scenarios into } \\
\text { Journal Breakdown Bundles }\end{array}\end{array}$} \\
\hline $\begin{array}{l}\text { Bundle } \\
\text { Name }\end{array}$ & Description & Scenarios & $\begin{array}{c}\text { No. of } \\
\text { Complaints }\end{array}$ \\
\hline No train & $\begin{array}{l}\text { In fact, or in effect, there is no train. If the } \\
\text { train is cancelled, does not depart, or } \\
\text { has already gone, the prospective passenger } \\
\text { must plan to do without this train. }\end{array}$ & $2,5,6,8,10$ & 29 \\
\hline Late train & $\begin{array}{l}\text { Trains that will not get to the destination } \\
\text { on time, stopping en route, or running } \\
\text { behind schedule. Passengers need to } \\
\text { know how they will be affected by falling } \\
\text { behind the timetable. }\end{array}$ & $\begin{array}{l}9,11,12,13, \\
15,17\end{array}$ & 34 \\
\hline Unexpected train & $\begin{array}{l}\text { Train ride is more expensive than } \\
\text { anticipated, or on a different schedule. } \\
\text { Passengers must find out if it is still } \\
\text { worthwhile boarding. }\end{array}$ & $3,4,7,14$ & 40 \\
\hline Incomplete journey & $\begin{array}{l}\text { Train will not get to the desired } \\
\text { destination. Passengers, or the train, miss } \\
\text { the stop, if the train even goes there. } \\
\text { Passengers have to find out how to get } \\
\text { to the destination from a new starting point. }\end{array}$ & $\begin{array}{l}7,10,12,13, \\
14\end{array}$ & 34 \\
\hline No problem & $\begin{array}{l}\text { People who cannot find their train, or who } \\
\text { have imminent departure, as long as they } \\
\text { make it on board. Also includes trips ahead } \\
\text { of schedule. This group does not need } \\
\text { recovery information. }\end{array}$ & $1,2,5,16$ & 8 \\
\hline
\end{tabular}

2 minutes for a connection, which it missed. He then missed the last train to Edinburgh and had to stay in London overnight. This passenger had used the NRES, departure notices, and staff, but was still unable to complete the journey as planned. He could have waited until the next day to make the trip, at less cost. One passenger, given contradictory information during service disruptions, elected to "forgo the delights of the rail system for the enormous convenience and considerably reduced cost of [his] private car."

Late Train. The second bundle covers situations where a passenger boards a train that will not reach the destination by the expected time. Here the passen- 
ger is limited to en-route information to discover how to proceed. Unless the passenger has time at a connecting station, information sources are limited to fellow passengers, conductors, telephone, and Internet. One man whose train was "traveling at snail speed" toward London because of a crane on the line, disembarked the moment he was near enough to the Underground because he knew London well enough to change modes. Many people are not aware of other routes or modes they could use. Access to appropriate information provision could assist. Out of 62 complaints with sufficient journey descriptions to allow further investigation, 28 could have been completed with delay savings if the passenger had taken an alternative mode, or caught another train.

Unexpected Train. The third bundle covers situations where there is a train ready for departure, but it is different from the one the passenger expects. It may have a different price or schedule, or the passenger may board the wrong train. The passenger must decide whether or not to continue with the journey. One embarrassed teacher had to use his own money to pay for a school trip, having been allegedly misquoted on the fare. All stations have now been supplied with NRES complaint forms to try to differentiate between genuine complaints and cases where the NRES is unjustly blamed.

Incomplete Journey. The fourth bundle is for incomplete journeys, where the passengers cannot get to their desired destination(s) without adding new legs to the trip. Some situations will be the same as those for "late train" or "unexpected train," but there are some additions. Passengers have boarded trains that have then failed to get to the destination. One passenger specifically asked for a Waterloo-Trowbridge train that stopped at Warminster, as he wanted to deliver a package. His train did not stop. A member of Parliament traveling from Market Harborough to Essex was not happy when a coach was laid on in place of a train. He commented that if he had wanted a bus he would have gone to the bus stop.

No Problem. The fifth bundle covers journeys that are problem free once the passenger boards the train. No one complained that their train arrived ahead of schedule, although one passenger did query why he was able to find a quick- 
er route than that provided by the NRES. The answer relates to the need for the NRES to allow certain lengths of time for connections, even though some passengers are able to cross platforms quicker, or catch different trains if theirs gets in early.

Letters assessed within each bundle highlighted, in some cases, the complexity of recovery options that people must endure, but also that, with appropriate information, recovery was possible (in at least 28 cases). They revealed an ability of some passengers to be effective in journey recovery, while others floundered with the added frustration of conflicting information. People do make use of available information sources, but their complaints clearly indicate a need for improvement in clarity, timeliness, and reliability.

\section{Existing Information Provision}

As mentioned, there is good access to pre-trip information. Prior to boarding a train, passengers can phone the NRES; use the Internet, information kiosks, paper timetables; or ask friends, station staff, or even people standing on the platform how to get from A to B. Once on board the train, access is more restricted. Here the primary source of information is the conductor, who can give out some information about how the train is expected to continue, but not about how to complete any particular journey. Passengers can still phone the NRES. It is estimated that 41 percent of the U.K. population have mobile phones (McIntosh 2000). Some handsets are now able to connect to the Internet and therefore offer access to Internet timetable services en route. However, if there is a problem with the information the NRES supplied, then passengers will not trust any new information, which may be out of date depending on the nature of the problem. From the complaints collected, 33 people tried to verify the information they were given. There were a number $(n)$ of trips where the NRES did not give correct information because of confusion over travel time $(n=9)$, schedule confusion: changed with insufficient warning or was incorrect information in the NRES database $(n=16)$, or there was an incident where NRES was not informed $(n=25)$. Although the 
popularity of the NRES reflects its overall quality of service, the reliability of information provided or its interpretation could be improved. This should reduce the number of journey breakdowns and, by implication, remove the need for journey recovery support.

Railtrack is keen for people to use the Internet to obtain information. None of the complaints analyzed referred to Internet information. This may be due to several reasons:

- none of the 105 complainants used this source of information;

- people complained directly to Railtrack;

- expectations concerning travel information from the Internet are not high enough to warrant complaining; or

- information from the Internet was accurate.

Railtrack surveyed website users for information they would like to see in addition to timetables (Figure 2). Nearly 15 percent of requests were for information on engineering works, (i.e., when the network was not expected to run normally). This was an issue that prompted 11 percent of the complaints to ATOC about actual journeys made.

Existing information system developments are at risk of being technology led. Assessment of complaint letters offers one means of gaining greater insight into how recovery information could be of greater benefit to passengers than scheduled timetable information, however well the latter might be presented across different media. Such insight can assist in promoting greater attention to user needs in future system developments.

\section{Compensation}

The complaints analysis shows that one-fourth of all complaints that ATOC received could have been avoided with more accurate information. ATOC paid $£ 1,313$ in compensation in response to the 105 complaints. Although only a crude approximation, if this figure is scaled up according to the total complaints to the 


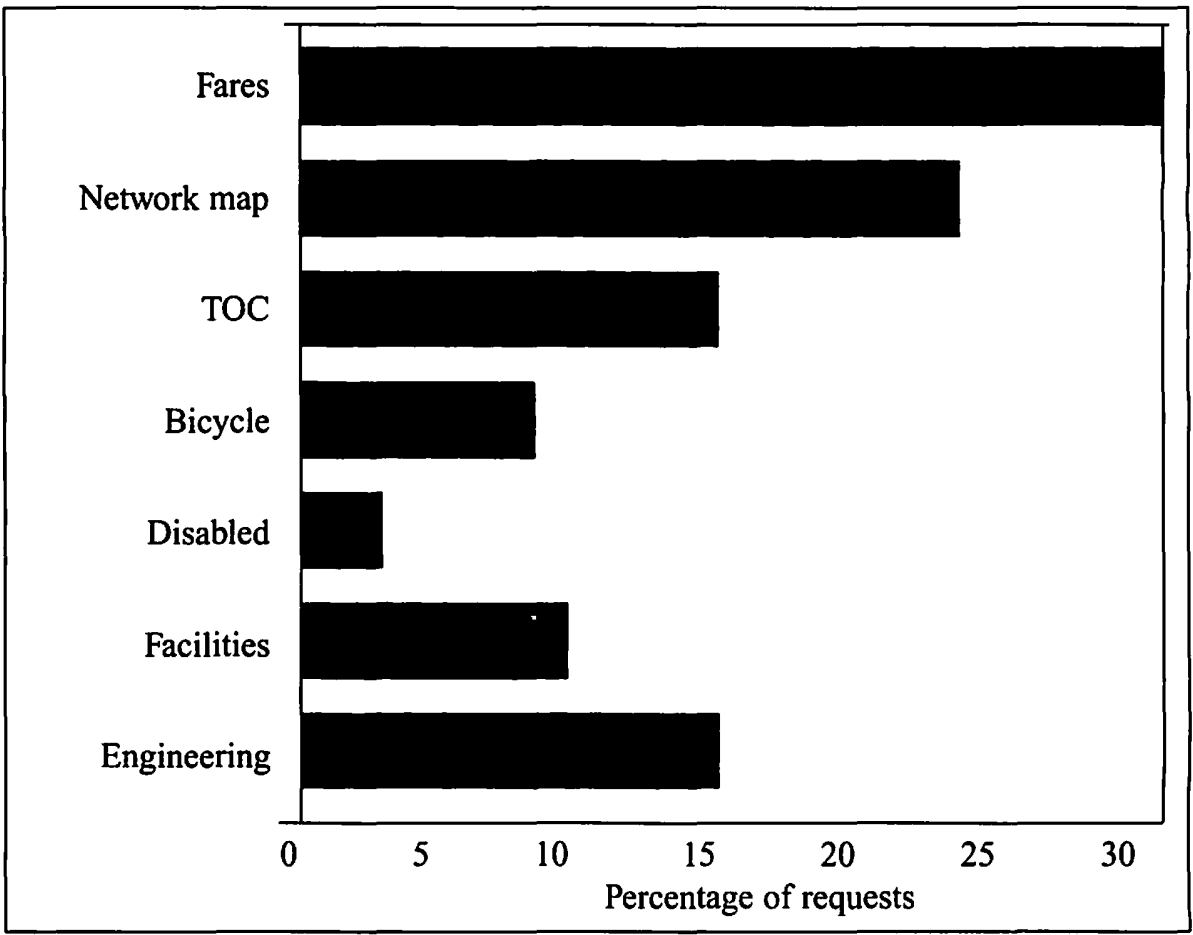

Source: Railtrack (2000)

Figure 2. Other types of information users would like to see on the Railtrack website

industry, compensation could be totaling approximately $£ 13,000,000$ per year.

The cost to the industry of journey breakdowns is likely to be much higher if other factors are taken into account. Not all breakdowns result in reported complaints. If passengers become discouraged by a bad experience, they may elect not to travel by rail in the future. Peoples' travel choices reflect their historical experience of the traveling environment (Adler and Blue 1998). Improved information provision has the potential to reduce the cost of journey breakdowns considerably.

\section{Conclusions}

This article has sought to illustrate the current and potential role of passenger information in supporting a rail industry that is still beleaguered by problems 
of train cancellations and punctuality. For long-distance journeys in the United Kingdom, the train has great potential as an alternative to the car. Yet in terms of passenger kilometers traveled per year, car travel has increased dramatically over the last 40 years while the level of rail travel has remained largely unchanged (Figure 3).

The government recognizes the importance of information in improving the awareness and attractiveness of public transport modes and in making journeys feel more seamless or easy to execute. The major complaint from passengers is about train service performance (Figure 1). There is scope for timely, accurate information to facilitate less disruptive progress of passengers through the rail network and alleviate some of the disruption resulting from poor performance.

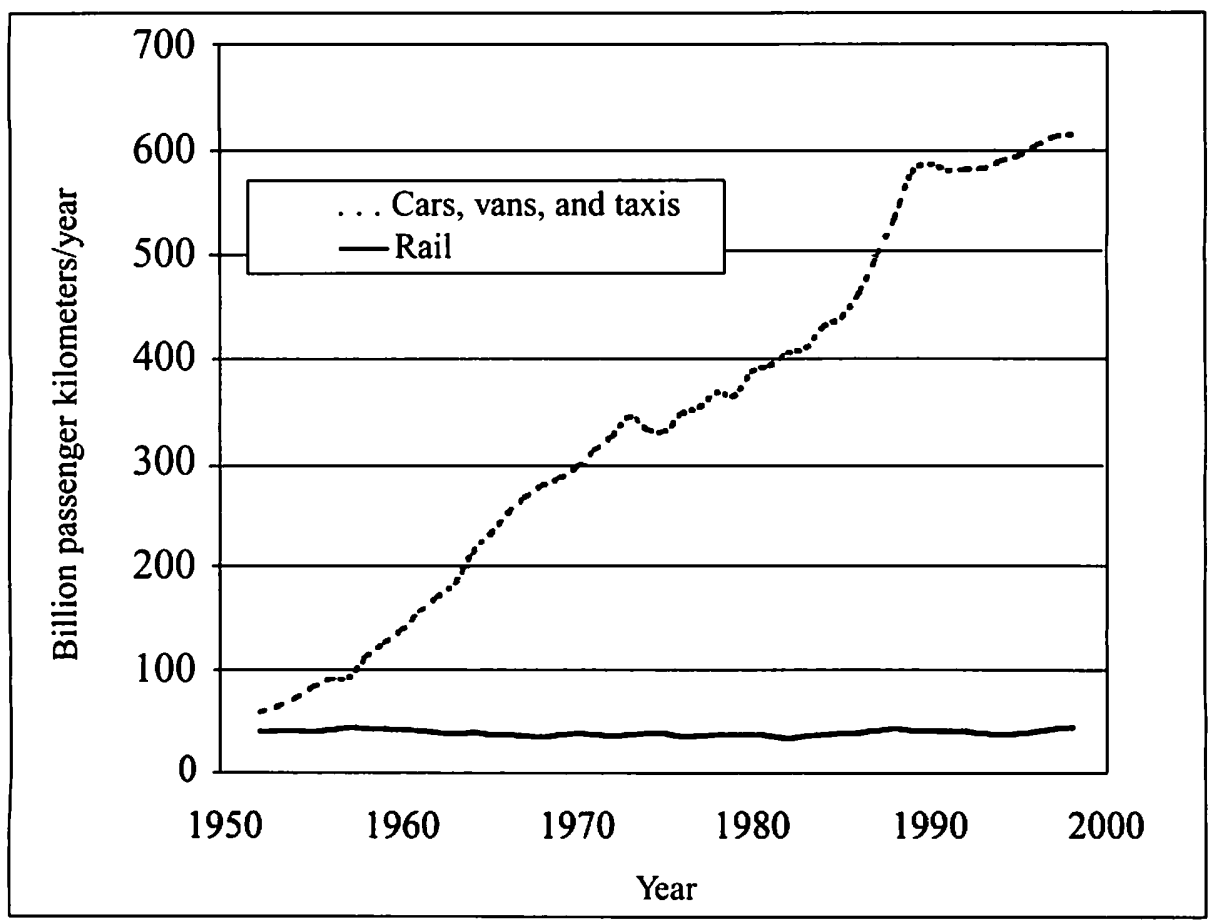

Source: DETR (1999).

Figure 3. Billion passenger kilometers/year traveled by mode: 1952-1998 
The passenger rail industry is evolving very good information systems for timetabled services and is beginning to address the need to take account of planned and unplanned deviations from the timetable. However, it appears that the specific value of information to passengers in journey breakdown situations is not being fully addressed.

This article has highlighted and conducted a preliminary examination of rail journey breakdown and recovery. The collective value of information to assist passengers in such situations has not yet been established. However, from the initial investigations of passenger complaints, there appears to be substantial potential for (enhanced) journey recovery information to improve both the plight of stranded passengers individually and the image of the passenger rail industry as a whole with the prospect of attracting higher levels of patronage.

\section{Acknowledgments}

The authors wish to extend their thanks to Richard Haste (formerly of ATOC) who provided a valuable source of up-to-date information concerning the passenger rail industry and particularly the NRES.

\section{References}

Adenso-Diaz B., Oliva M. Gonzalez., and P. Gonzalez-Torre. 1999. On-line timetable rescheduling in regional train services. Transportation Research B 33(6): 387-389.

Adler J., and V. Blue. 1998. Towards the design of intelligent traveler information systems. Transportation Research C 6(3):157-172.

Anderson T. 1993. Real-time passenger information for transit systems: Proposals for the Jubilee Line extension. Proceedings, PTRC 21st European Transport Forum.

Association of Train Operating Companies. 2000. National Rail Enquiries http://www.rail.co.uk/atoc/public/levl/who_enq.htm (viewed 02/09/00). 
British Railways Board. 1963. The reshaping of the railways.

Campbell J. 1998. New direction for ScotRail. ITS International: March/April: 64-65.

Computing. July 23, 1998. Full steam ahead for U.K. rail database. 11.

Department of the Environment, Transport and the Regions. 1998. A new deal for transport: better for everyone. Transport White Paper, London, TSO.

Department of the Environment, Transport and the Regions. 1999. Transport statistics Great Britain 1999. London, TSO.

Higgins A., and E. Kozan. 1998. Modeling train delays in urban networks. Transportation Science 32(4): 346-357.

Her Majesty's Stationery Office. 1983. Railway finances. Report of committee chaired by Sir David Serpell.

Internet Magazine. 1999. Trendspotting. December.

Leake J., and M. Macaskill. March 5, 1998. Trains were faster in the last century. The Sunday Times.

Le Squeren. 1991. Passenger information. Proceedings, DRIVE Conference: Advanced Telematics in Transport 2.

Lyons, G. D. 1999. U.K. passenger transport information on the Internet: Promoting best practice through accreditation. Proceedings, European Transport Conference Public Transport Planning and Management: 127-138, Cambridge.

McIntosh. January 6, 2000. Handset sales near 50,000 a day as mobile phone fever grips UK. The Independent. 
Office for National Statistics. 2000. The U.K. in Figures. http://www.statistics.gov.uk/stats/ukinfigs/stand.htm (viewed 02/09/00).

Office of the Rail Regulator. 1999. Rail Complaints Bulletin. Report No. 3, 1998/1999.

Organization for Economic Cooperation and Development. 1998. Railways:

Structure regulation and competition policy. annex. The restructured railway in Great Britain DAFFE/CLP(98)1: 136-139.

Railtrack. 2000. What Other Information Would You Like to See on This Site? http://www.railtrack.co.uk/travel/feedback/index.html (viewed 02/09/00).

Shadow Strategic Rail Authority. September 16, 1999. Quarterly Performance Bulletin.

Welsby, J., and A. Nichols. 1999. The privatization of Britain's railways: An inside view. Journal of Transport Economics and Policy 33(1): 55-76.

White P. 1998. Impacts of rail privatization in Britain. Transport Reviews 18(2): 109-130.

\section{About the Authors}

GLENN LYONs (G.Lyons@soton.ac.uk) is a lecturer in transportation planning and a member of the Transportation Research Group at the University of Southampton. He has several years of research experience concerning traveler information systems (with an emphasis on user requirements) and the use of the Internet for information dissemination. He is a member of the institute of Logistics and Transportation's Accreditation Panel for Internet sites providing public transport information. 
GraEME MCLAY (G.McLay@soton.ac.uk) is a postgraduate student in the Transportation Research Group with degrees in philosophy (with psychology) and information technology. He is investigating passenger information needs for rail travel. 